\title{
МОРФОМЕТРИЧНА ХАРАКТЕРИСТИКА СЛИЗОВОЇ ОБОЛОНКИ ПОРОЖНИНИ РОТА І ЗМІНИ ПОКАЗНИКІВ ГУМОРАЛЬНОГО ІМУНІТЕТУ ПРИ ВПЛИВІ РІЗНИХ ТИПІВ ЗАПАЛЬНОЇ РЕАКЦІЇ ЗА УМОВИ ЕКСПЕРИМЕНТАЛЬНОГО ГАСТРОДУОДЕНІТУ
}

Вступ. Слизова оболонка порожнини рота є чутливим індикатором оцінки патологічних процесів шлунково-кишкового тракту, що зумовлено відмінністю їі від інших слизових оболонок за морфологічними ознаками. При захворюванні органів травлення, залежно від глибини ураження того чи іншого органа, розвиваються морфологічні зміни слизової оболонки всіх відділів порожнини рота і зміни імунологічних показників у крові тварин.

Мета дослідження - вивчити та оцінити зміни морфометричних параметрів слизової оболонки порожнини рота щічної ділянки і зміни показників гуморального імунітету при впливі різних типів запальної реакції за умови експериментального гастродуоденіту.

Методи дослідження. Експеримент виконано на 84 щурах-самцях масою 180-200 г. В усіх тварин протягом 7-ми днів моделювали гострий гастродуоденіт. Гіпоергічний тип запальної реакції моделювали шляхом внутрішньом'язового введення алкілуючого цитостатика циклофоосфану, гіперергічний пірогеналу. Нормоергічний тип розвивався в щурів з експериментальним гастродуоденітом без додаткового введення будь-яких речовин. Анатомічне препарування щічної ділянки рота і морфометричні вимірювання здійснювали за методикою Г. Г. Автанділова. Вимірювали товщину слизової оболонки, епітеліального шару, власної пластинки, базальної мембрани, питому вагу пошкоджених епітеліоцитів остеоподібного шару, відносний об'єм капілярів. У сироватці крові тварин визначали рівні $\lg A, M, G$.

Результати й обговорення. На основі отриманих морфометричних даних вивчено та встановлено зміни слизової оболонки порожнини рота. Причиною зменшення товщини слизової оболонки щоки було значне стоншення епітеліального шару. Водночас інші структурні компоненти слизової оболонки порожнини рота щічної ділянки, а саме базальна мембрана та власна пластинка, навпаки, потовщувалися. Максимально виражені дистрофрічні зміни епітелію слизової оболонки щоки при мікроскопії було виявлено у тварин з гіперергічним типом запальної реакції. Питома вага пошкоджених епітеліоцитів на 10-ту добу дослідження за показниками була збільшена відносно контролю в перелічених групах. У щурів з гіпер-, нормо- та гіпоергічним типами запальної реакції морфрометричні зміни щічної ділянки узгоджувалися 3 імунологічними показниками. Рівні Ig A, M, G були вищими відносно контролю в усіх досліджуваних групах тварин.

Висновки. Зміни морфометричних даних супроводжувалися зменшенням товщини слизової оболонки й епітеліального шару, збільшенням товщини власної пластинки, базальної мембрани, питомої ваги пошкоджених епітеліоцитів остеоподібного шару та відносного об'єму капілярів упродовж 10-ти діб експерименту незалежно від типу запальної реакції, зміни гуморального імунітету - зростанням рівнів Ig A, M, G відносно контролю впродовж 10-ти діб. Найбільш значні зміни було виявлено у тварин з гіперергічним типом запальної реакції, найменші - з гіпоергічним, у щурів з нормоергічним типом зміни займали проміжне місце.

КЛЮЧОВІ СЛОВА: морфометрія; слизова оболонка порожнини рота; гастродуоденіт; гіпоергічний тип запальної реакції; нормоергічний тип запальної реакції; гіперергічний тип запальної реакції; імуноглобуліни класів A, M, G.

ВСТУП. Слизова оболонка порожнини рота $€$ чутливим індикатором оцінки патологічних процесів шлунково-кишкового тракту $[6,16]$, що зумовлено відмінністю її від інших слизових оболонок за морфологічними ознаками [3, 15]. Для її епітелію характерною є провідна роль у реалізації захисних механізмів, до яких належать (с) В. І. Бондарчук, 2017 висока фрерментативна активність, висока інтенсивність обмінних процесів, наявність у незроговілому епітелії великої кількості глікогену і його здатність до швидких перебудов $[9,15]$. При захворюванні органів травлення, залежно від глибини ураження того чи іншого органа, розвиваються морфологічні зміни слизової оболонки всіх відділів порожнини рота $[3,15,16]$ та зміни 
імунологічних показників у крові тварин $[4,7,8]$. Частота дегенеративних уражень слизової оболонки порожнини рота останнім часом невпинно зростає, що зумовлено дією як екзо-, так і ендогенних фракторів $[4,9,15,16]$. Однак на даний час залишаються суперечливими наукові дані про характер і ступінь проявів морфометричних змін тканин порожнини рота різної локалізації, зокрема щічної ділянки, та зміни показників гуморального імунітету при впливі різних типів запальної реакції (ТЗР) за умови експериментального гастродуоденіту (ГД). Тому вказана проблематика є важливою, актуальною і вимагає свого вирішення.

Мета дослідження - вивчити та оцінити зміни морфометричних параметрів слизової оболонки порожнини рота щічної ділянки і зміни показників гуморального імунітету при впливі різних типів запальної реакції за умови експериментального гастродуоденіту.

МЕТОДИ ДОСЛІДЖЕННЯ. Експеримент виконано на 84 щурах-самцях масою 180-200 г, яких утримували у звичайних умовах на стандартному раціоні віварію відповідно до Науковопрактичних рекомендацій з утримання лабораторних тварин та роботи з ними (Ю.М.Кожем'якін та співавт., 2002) і положень Європейської конвенції про захист хребетних тварин, що використовуються для дослідних та інших наукових цілей [10], а також Загальних етичних принципів експериментів на тваринах [14].

В усіх тварин протягом 7-ми днів моделювали гострий ГД шляхом зондового введення у шлунок 0,25 мл $10 \%$ розчину етилового спирту $\left(\mathrm{C}_{2} \mathrm{H}_{5} \mathrm{OH}\right)$ та через 5 хв - 0,5 мл 1,25\% розчину соляної кислоти (HCl) [13]. Гіпоергічний ТЗР моделювали шляхом внутрішньом'язового введення алкілуючого цитостатика циклооросфану (ВАТ "Київмедпрепарат", Україна) в дозі 10 мг/кг маси тіла за 3 дні до моделювання експериментального ГД і щоденно протягом 7-ми наступних днів [11], гіперергічний ТЗР - шляхом внутрішньом'язового введення пірогеналу (НДІЕМ ім. М. Ф. Гамалеї РАМН, Росія) на фрізіологічному розчині (5 мінімальних пірогенних доз на одну тварину) за день до моделювання експериментального ГД і щоденно протягом 7-ми днів [12]. Нормоергічний ТЗР розвивався в щурів з експериментальним ГД без додаткового введення будь-яких речовин. Для проведення дослідження тварин було поділено на чотири групи (по шість щурів у кожній): 1-ша - інтактні тварини (контроль); 2-га - тварини з нормоергічним ТЗР; 3-тя - тварини з гіпоергічним Т3Р; 4-та - тварини з гіперергічним ТЗР. Щурів виводили з експерименту шляхом швидкої декапітації під тіопен- тал-натрієвим наркозом шляхом внутрішньочеревного введення 5\% розчинутіопентал-натрію з розрахунку 1 мл на 100 г маси тіла тварини на 7-му та 10-ту доби після моделювання гострого ГД.

Анатомічне препарування щічної ділянки рота і морфометричні вимірювання здійснювали за методикою Г. Г. Автанділова $[1,2]$. При моророметричному дослідженні вимірювали товщину слизової оболонки, епітеліального шару, власної пластинки, базальної мембрани, питому вагу пошкоджених епітеліоцитів остеоподібного шару, відносний об'єм капілярів. Морфометричну оцінку здійснювали за допомогою окулярмікрометра МOB-1-15×. Вимірювання проводили на чотирьох гістологічних мікропрепаратах у кожного щура групи (n=24).

Використовуючи напівавтоматичний біохімічний аналізатор "Humalyzer 2000" та набори реактивів фрірми “Нuman”, у сироватці крові тварин визначали рівень концентрації Ig A, M, G [5].

Обробку результатів виконано у відділі системних статистичних досліджень Тернопільського державного медичного університету імені І. Я. Горбачевського в програмному пакеті Statsoft STATISTICA. Для обробки числових величин і об'єктивної оцінки ступеня достовірності результатів дослідження використано варіаційно-статистичний метод аналізу даних. Визначали середню величину (М), її похибку (m). Достовірність різниці значень між незалежними кількісними величинами визначали за допомогою критерію Манна-Уїтні. Результати вважали статистично вірогідними при $р<0,05$.

РЕЗУЛЬТАТИ Й ОБГОВОРЕННЯ. На ОСНОВі отриманих морфометричних даних вивчено та встановлено зміни слизової оболонки порожнини рота. Загальна товщина слизової оболонки щоки у контрольних тварин складала $(469,27 \pm 12,31)$ мкм, тоді як у щурів 3 нормоергічним ТЗР спостерігали її стоншення. Зокрема, на 7-му добу дослідження у тварин з нормоергічним ТЗР різниця становила 9,4\% $(p<0,05)$, в щурів з гіперергічним Т3Р - 13,8 \% ( $p<0,001)$. На 10-ту добу різниця показника у тварин з нормоергічним ТЗР становила 9,9\% ( $<<0,001)$, в щурів 3 гіперергічним ТЗР - 21,1 \% ( $<<0,001)$ відповідно. Товщина слизової оболонки щоки у тварин 3 нормоергічним ТЗР складала $(425,01 \pm 11,34)$ мкм. Порівняно 3 групою щурів 3 гіперергічним ТЗР показник на 10-ту добу знизився на 15,1 \% $(\mathrm{p}<0,05)$. Товщина слизової оболонки щоки у тварин з гіпоергічним ТЗР на 10-ту добу дослідження, порівняно з групою щурів з гіперергічним ТЗР, була більшою на 15,1 \% (p<0,001). Причиною зменшення товщини слизової оболонки 
щоки було значне стоншення епітеліального шару, що можна пояснити дистрофрічними змінами різної інтенсивності. Водночас інші структурні компоненти слизової оболонки порожнини рота щічної ділянки, а саме базальна мембрана та власна пластинка, навпаки, потовщувалися (табл.).

Максимально виражені дистрофрічні зміни епітелію слизової оболонки щоки при мікроскопії було виявлено у тварин з гіперергічним ТЗР. Це знайшло своє відображення і при морфометричному дослідженні: товщина епітеліального шару в щурів цієї експериментальної групи зменшувалася відносно контролю $(311,08 \pm 5,05)$ мкм, на 7-му добу дослідження показник був нижчим на $15,7 \%$ (p<0,001), а на 10-ту - на 22,3\% ( $<<0,001)$. У тварин з нормоергічним ТЗР стоншення епітелію, порівняно з контролем, було менш вираженим. Окрім того, не відмічали істотної відмінності в різні терміни експерименту: на 7-му добу дослідження регресія морфометричного показника становила $12,1 \%(p<0,05)$, на 10-ту - 12,7 \% $(p<0,001)$. Варто врахувати те, що на 10-ту добу дослідження при порівнянні показника у тварин 3 нормоергічним ТЗР і щурів з гіперергічним ТЗР різниця складала 22,3\% $(\mathrm{p}<0,05)$.

Товщина базальної мембрани епітелію щічної ділянки порожнини рота у контрольних тварин становила $(10,32 \pm 0,21)$ мкм. Ії̈ потовщення спостерігали у всіх експериментальних групах. У щурів з нормоергічним ТЗР на 7-му добу дослідження приріст становив 12,1\% $(p<0,05)$, у тварин 3 гіпоергічним ТЗР - 11,5\% $(p<0,05)$, в щурів 3 гіперергічним ТЗР - 29,2\% $(p<0,001)$. На 10-ту добу дослідження показник також був вищим - на 13,1 \% ( $<<0,05), 8,9 \%$ $(p<0,05), 34,4 \%(p<0,001)$ відповідно. За результатами морфометричного дослідження, наслідком потовщення базальної мембрани стало порушення трофріки епітеліоцитів 3 їх подальшою дистрофрією. У тварин з нормоергічним ТЗР товщина базальної мембрани епі-

Таблиця - Мікроморфометрична характеристика слизової оболонки щоки в білих щурів при різних типах запальної реакції (10-та доба дослідження)

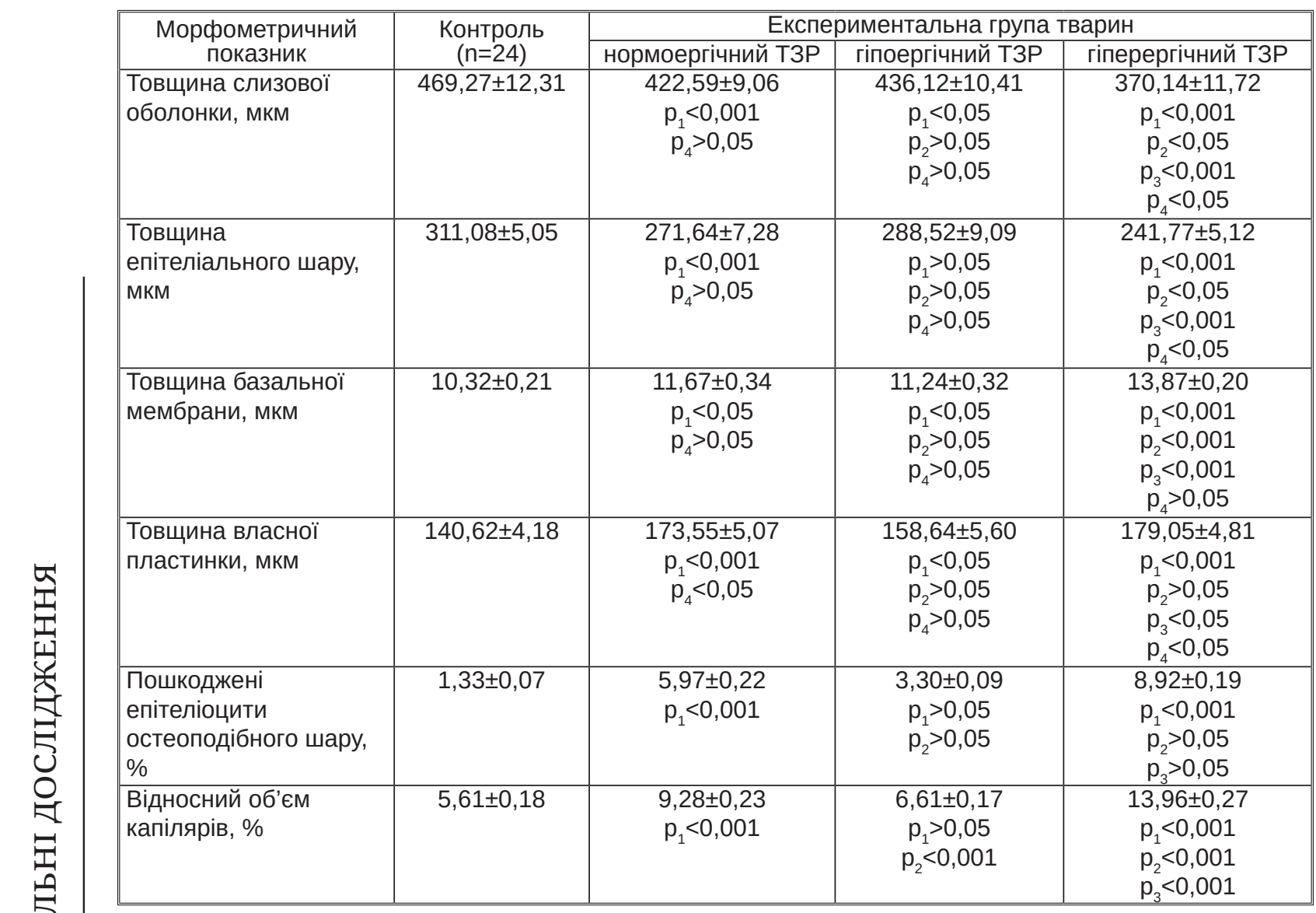

Примітки:

1. $n=24$, оскільки вимірювання проводили на чотирьох гістологічних мікропрепаратах у кожного щура групи.

2. $\mathrm{p}_{1}$ - зіставлення з контрольною групою.

3. $\mathrm{p}_{2}$ - зіставлення зі щурами з нормоергічним ТЗР.

4. $\mathrm{p}_{3}$ - зіставлення зі щурами з гіпоергічним ТЗР.

5. $\mathrm{p}_{4}$ - зіставлення з аналогічною групою на 7-му добу дослідження. 
телію щічної ділянки порожнини рота, порівняно зі щурами з гіперергічним ТЗР, була меншою на 7-му добу дослідження на 15,3 \% (p<0,001), на 10-ту - на 34,4 \% ( $<<0,001)$ (табл.). Варто відмітити, що досліджуваний показник у групі тварин з гіпоергічним ТЗР, порівняно зі щурами з гіперергічним ТЗР, був нижчим на 7-му добу дослідження на 15,8 \% ( $p<0,001)$, на 10-ту - на 23,4\% (p<0,001).

Вимірювання власної пластинки слизової оболонки порожнини рота щічної ділянки засвідчило, що її товщина у групі контролю становила $(140,62 \pm 4,18)$ мкм. У тварин 3 нормоергічним ТЗР виявлено потовщення власної пластинки на 13,4\% (p<0,05), в щурів з гіперергічним Т3Р на 14,7\% $(p<0,05)$. Такі зміни мали місце на 7-му добу дослідження, а через 3 доби величина приросту товщини lamina propria mucosae, порівняно $з$ контролем, складала у тварин з нормоергічним Т3Р 23,4 \% ( $<<0,001)$, в щурів з гіпоергічним ТЗР - 12,8 \% ( $<<0,05)$, у тварин з гіперергічним ТЗР -27,3\% $\%$ ( $<0,001)$.

Важливим індикатором процесів альтерації у слизовій оболонці порожнини рота є питома вага пошкоджених епітеліоцитів. У контрольній групі морорологічно змінені епітеліоцити становили $(1,33 \pm 0,07)$ \%. На 7-му добу дослідження частка пошкоджених клітин епітелію у тварин 3 нормоергічним ТЗР була вищою на 3,8 \% ( $p<0,001)$, в щурів з гіперергічним Т3Р - на 6,1\% ( $p<0,001)$. На 10-ту добу дослідження показник збільшився відносно контролю в перелічених групах, відповідно, на 4,6 і 7,6 \%. Статистично значиму відмінність було відмічено при зіставленні 3 показником контрольних тварин $(p<0,001)$.

Суттєву роль у патогенезі змін слизової оболонки порожнини рота щічної ділянки при змодельованому ГД на фроні різних типів запальної реакції відіграло порушення кровообігу. При морфометричному дослідженні це проявилося інтенсифікацією величини відносного об'єму капілярів. У контрольних тварин відносний об'єм капілярів слизової оболонки порожнини рота щічної ділянки становив $(5,61 \pm 0,18) \%$. У тварин 3 нормоергічним ТЗР на 7-му добу дослідження відносний об'єм капілярів був більшим на 2,8 \%, у групі щурів з гіперергічним ТЗР - на 5,6 \%. На 10-ту добу дослідження прогресія морфометричного показника складала 3,7 та 8,4% (p<0,001). У щурів з нормоергічним ТЗР відносний об'єм капілярів, порівняно з групою тварин з гіперергічним ТЗР, на 7-му добу дослідження був меншим на 2,9\% (p<0,001), а на 10-ту - на 4,7\% (p<0,001). При порівнянні показника групи тварин з гіпоергічним ТЗР із показником щурів з нормоергічним ТЗР виявлено його зниження на 10-ту добу до- слідження на 2,7 \% (p<0,001). Відносний об'єм капілярів у тварин з гіперергічним ТЗР, порівняно з показником щурів з гіпоергічним ТЗР, на 7-му добу дослідження був більшим на 5,1 \%. На 10-ту добу дослідження показник підвищився на $7,4 \%(p<0,001)$.

У білих щурів-самців з гіпер-, нормо- та гіпоергічним ТЗР морфометричні зміни щічної ділянки узгоджувалися з імунологічними показниками. Було встановлено, що рівні Ig A, M, G були вищими відносно контролю в усіх експериментальних групах тварин (рис.).

Рівень Ig А був найбільшим у групі тварин 3 гіперергічним ТЗР $((0,991 \pm 0,004)$ г/л), найменший показник відмічено в щурів 3 гіпоергічним ТЗР $((0,714 \pm 0,002)$ г/л), тварини з нормоергічним ТЗР займали проміжне положення між гіпер- та гіпоергічним ТЗР $((0,910 \pm 0,002)$ г/л). У групі щурів з гіперергічним ТЗР показник був найвищим ((0,938 0,014$)$ г/л), тварини з нормоергічним ТЗР займали проміжне місце $((0,913 \pm 0,003)$ г/л). У щурів з гіпоергічним ТЗР рівень Ig М був найнижчим $((0,899 \pm 0,005)$ г/л). У групі тварин 3 гіперергічним ТЗP рівень Ig G мав найвищий показник $((1,433 \pm 0,002)$ г/л). Рівень Ig G у групі щурів 3 нормоергічним ТЗР займав проміжне місце $((1,414 \pm 0,003)$ г/л). У тварин з гіпоергічним ТЗР рівень Ig G був нижчим, ніж у групі щурів 3 нормо- та гіперергічним ТЗР $((1,402 \pm 0,002)$ г/л).

У тварин з гіперергічним ТЗР рівень Ig А був вищим на 7-му добу дослідження на $76 \%$ $(p<0,05)$, на 10-ту - на 78,2 \% ( $<<0,05)$, рівень Ig $\mathrm{M}$ - на 24,4 \% (p<0,05) та 23,4 \% (p<0,05) відповідно, рівень Ig G - на $69 \%(p<0,05)$ і 70,1 \% $(p<0,05)$. При порівнянні показника цієї групи щурів з показником тварин з нормоергічним ТЗР виявлено, що рівень Ig А був більшим на 7-му добу дослідження на 9,1 \% (p<0,05), на 10-ту - на 8,9 \% (p<0,05). При порівнянні тієї ж групи щурів із тваринами з гіпоергічним ТЗР слід відмітити, що рівень $\lg$ А був вищим на 7-му добу дослідження на 39,4 \% (p<0,05), на 10-ту - на 38,8 \% $(p<0,05)$.

У тварин 3 нормоергічним ТЗР, порівняно 3 контролем, рівень $\lg$ А був більшим на 7-му добу дослідження на 61,3 \% (p<0,05), на 10-ту - на $63,6 \%$ (p<0,05), рівень Ig M - на 20,5 \% (p<0,05) та $21 \%(p<0,05)$ відповідно, рівень Ig $\mathrm{G}$ - на $67,9 \%(p<0,05)$ і 66,6 \% (p<0,05). При порівнянні показника цієї ж групи щурів з показником тварин з гіпоергічним ТЗР встановлено, що рівень Ig А був вищим на 7-му дослідження на $27,7 \%(p<0,05)$, на 10-ту - на 27,4 \% (p<0,05). Порівняно з групою тварин з гіперергічним ТЗР варто відмітити зниження рівня Ig А на 7-му добу дослідження на 8,3 \% (p<0,05), на 10-ту - на $8,1 \%(p<0,05)$. 


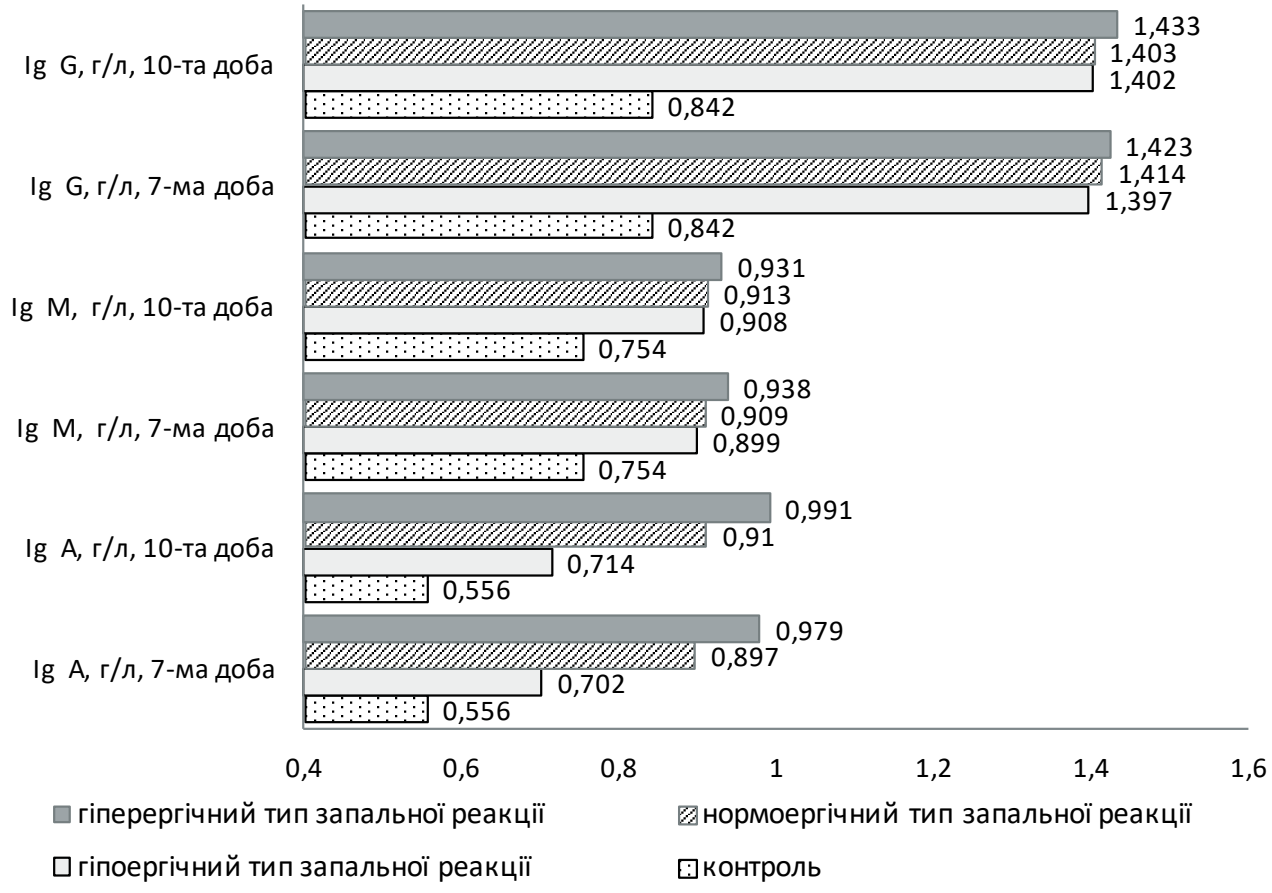

Рис. Зміна рівнів імуноглобулінів A, M, G у сироватці крові тварин експериментальних груп.

У тварин 3 гіпоергічним ТЗР, порівняно 3 контролем, рівень Ig А був вищим на 7-му добу дослідження на $26,2 \%(p<0,05)$, на 10-ту - на $28,4 \%(p<0,05)$, рівень Ig $M-$ на $19,2 \%(p<0,05)$ та 20,4\% (p<0,05) відповідно, рівень lg G - на $65,9 \%(p<0,05)$ і $66,5 \%(p<0,05)$. У тварин 3 гіпоергічним ТЗР, порівняно зі щурами з нормоергічним ТЗР, рівень Ig А був нижчим на 7-му добу дослідження на 21,7 \% (p<0,05), на 10-ту $21,5 \%(p<0,05)$. Порівняно з показником тварин 3 гіперергічним ТЗР рівень Ig А був меншим на 7-му добу дослідження на 28,2 \% ( $<<0,05)$, на 10-ту - на 27,9 \% $(p<0,05)$.

Отримані результати свідчать про те, що зміни морфометричних та імунологічних показників залежать від типу запальної реакції та супутнього захворювання.

ВИСНОВКИ. 1. Найбільш значні зміни морсоометричних даних виявлено у тварин 3 гіперергічним типом запальної реакції, в яких товщина слизової оболонки відносно контролю зменшилася на $21,1 \%$ ( $<<0,001)$, епітеліального шару - на 22,3 \% ( $<<0,001)$, а базальної мембра- ни та власної пластинки - збільшилася на 34,4 \% $(p<0,001)$ та 27,3\% $(p<0,001)$ відповідно. У щурів 3 гіпоергічним типом запальної реакції морфометричні зміни були найменш значними.

2. Зміни морфометричних даних супроводжувалися зменшенням товщини слизової оболонки й епітеліального шару, збільшенням товщини власної пластинки, базальної мембрани, питомої ваги пошкоджених епітеліоцитів остеоподібного шару та відносного об'єму капілярів упродовж 10 діб експерименту незалежно від типу запальної реакції.

3. Зміни гуморального імунітету супроводжувалися зростанням рівнів $\lg \mathrm{A}, \mathrm{M}, \mathrm{G}$ відносно контролю впродовж 10 діб. Найбільш значні зміни було виявлено у тварин з гіперергічним типом запальної реакції, найменші - 3 гіпоергічним, у щурів з нормоергічним типом зміни займали проміжне місце.

Перспективи подальших досліджень полягали у вивченні особливостей ремоделювання структурних компонентів щічної ділянки при впливі різних типів запальної реакції за умови експериментального гастродуоденіту.

\section{СПИСОК ЛІТЕРАТУРИ}

1. Автандилов Г. Г. Медицинская морфометрия / Г. Г. Автандилов. - М. : Медицина, 1990. - 418 с.

2. Автандилов Г. Г. Основы количественной патологической анатомии / Г. Г. Автандилов. - М. : Медицина, 2002. - 240 с.
3. Білаш С. М. Структурна характеристика епітеліального шару твердого піднебіння людини / С. М. Білаш // Вісн. проблем біології і медицини. - 2006. Вип. 2. - С. 182-183. 
4. Борисенко М. І. Імуномодуляція місцевого імунітету верхніх відділів травного каналу при хронічному запальному процесі його слизової оболонки / М. І. Борисенко // Сучасна гастроентерологія. - 2006. № 1 (27). - C. 41-45.

5. Гриневич Ю. А. Определение иммунных комплексов в крови онкологических больных / Ю. А. Гриневич, А. М. Алферов // Лаб. дело. - 1981. - № 8. C. 493-495.

6. Запалення - типовий патологічний процес / М. С. Регеда, Т. С. Бойчук, Ю. І. Бондаренко, М. М. Регеда. -2-ге вид., доповн. та переробл. - Львів, 2013. $148 \mathrm{c}$.

7. Кайдашев И. П. Очерки иммунобиологии слизистой оболочки полости рта / И. П. Кайдашев. - Полтава, 2008. - 304 с.

8. Климович В. Б. Иммуноглобулин А (IgA) и его рецепторы / В. Б. Климович, М. П. Самойлович // Мед. иммунология. - 2006. - 8, № 4. - С. 483-500.

9. Морсометрические исследования эпителиоцитов слизистой оболочки щеки крыс после овариоэктомии и введения ЕКСО / А. Б. Македон, И. Н. Моисеев, В. Н. Почтарь, В. Я. Скиба // Вісн. стоматології. 2004. - № 1. - С. 11-15.

10. Науково-практичні рекомендації з утримання лабораторних тварин та роботи з ними / Ю. М. Кожем'якін, О. С. Хромов, М. А. Філоненко, Г. А. Сайсретдінова. - К. : Авіцена, 2002. - 156 с.

11. Пат. 57189 Україна, МПК (2011.01) А61К 31/00 G09B 23/28 (2006.01). Спосіб моделювання пародонти- та/ Авдєєв О. В. ; заявникі патентовласник Терноп. держ. мед. ун-т імені І. Я. Горбачевського. - № u201010071 ; заявл. 16.08.10 ; опубл. 10.02.11, Бюл. № 3.

12. Пат. 66298 Україна, МПК А61К 39/104 (2006.01) G09B 23/28 (2006.01). Спосіб моделювання пародонтиту/Авдєєв О. В. ; заявникіпатентовласник Терноп. держ. мед. ун-т імені І. Я. Горбачевського. - № u201108090 ; заявл. 29.06.11 ; опубл. 26.12.11, Бюл. № 24.

13. Пат. 98021 Україна, МПК (51) G09B 23/78 G01N 23/48 G01N 33/84 G01N 33/98 (2006.01). Спосіб моделювання запальних процесів слизової оболонки порожнини рота / Мисула Н. І., Авдєєв О. В. ; заявник і патентовласник Терноп. держ. мед. ун-т імені І. Я. Горбачевського. - № u201010071 ; заявл. и 2014 12673; опубл. 10.04.15, Бюл. № 7.

14. Резніков О. Г. Загальні етичні принципи експериментів на тваринах. Перший національний конгрес з біоетики / О. Г. Резніков // Ендокринологія. - 2003. № 1 (8). - С. 142-145.

15. Романенко Е. Г. Структурные изменения в слизистых оболочках верхних отделов пищеварительного тракта при экспериментальном гастродуодените [Электронный ресурс]/Е. Г. Романенко // Морфологія. 2013. - VII, № 1. - С. 73-77. - Режим доступа к журн. : http://www.morphology.dp.ua/.

16. Трухан Л. Ю. Изменение со стороны органов и тканей полости рта при болезнях органов пищеварения / Л. Ю. Трухан, Л. В. Тарасова, Д. И. Трухан // Клинич. практика. - Dental Tribune Russian Edition. 2012. - № 2. - C. 10.

\section{REFERENCES}

1. Avtandilov, G.G. (1990) Meditcinskaia morfometriia [Medical morphometry]. Moscow: Meditsina [in Russian].

2. Avtandilov, G.G. (2002) Osnovy kolichestvennoi patologicheskoi anatomii [Fundamentals of quantitative pathological anatomy]. Moscow: Meditsina [in Russian].

3. Bilash, S.M. (2006) Strukturna kharakterystyka epitelialnoho sharu tverdoho pidnebinnia liudyny [The structural characterization of the epithelial layer of the hard palate of a man]. Visnyk problem biolohii i medytsyny - Journal of Problems of Biology and Medicine, 2, 182-183 [in Ukrainian].

4. Borysenko, M.I. (2006) Imunomoduliatsiia mistsevoho imunitetu verkhnikh viddiliv travnoho kanalu pry khronichnomu zapalnomu protsesi yoho slyzovoi obolonky [Monomodular local immunity of the upper digestive canal when chronic inflammatory process of the mucous membrane]. Suchasna hastroenterolohiia - Modern Gastroenterology , 1 (27), 41-45 [in Ukrainian].

5. Grinevich, Yu.A., \& Alferov, A.M. (1981). Opredelenie immunnykh kompleksov $v$ krovi onkologicheskikh bolnykh [Determination of immune complexes in the blood of cancer patients]. Laboratornoe delo-Laboratory work, 8. 493-495 [in Russian].

6. Reheda, M.S., Boichuk, T.S., Bondarenko, Yu.I., \&Reheda, M.M. (2013). Zapalennia-typovyipatolohichnyi protses [Inflammation is a typical pathological process]. Lviv: Vyd.druhe, dop. ta perer. [in Ukrainian].
7. Kaidashev, I.P. (2008) Ocherki immunobiologii slizistoi obolochki polosti rta [Studies in the immunobiology of the mucous membrane of the oral cavity]. Poltava: Polymet [in Russian].

8. Klimovich, V.B. \& Samoilovich, M.P. (2006). Immunoglobulin A (IgA) i ego retseptory [Immunoglobulin A ( $\lg A)$ and its receptor]. Med. immunologiia. - Medical Immunology, 8 (4), 483-500 [in Russian].

9. Makedon, A.B., Moiseev, I.N., Pochtar, V.N., \& Skiba, V.Ya. (2004). Morfometricheskie issledovaniia epiteliotsitov slizistoi obolochki shcheki krys posle ovarioektomii i vvedeniia EKSO [Morphometric study of epithelial cells of buccal mucosa of rats after ovariectomy and the introduction of EKSO]. Visnik stomatologii Journal of Dentistry, 1. 11-15 [in Russian].

10. Kozhemiakin, Yu.M., Khromov, O.S., Filonenko, M.A. \& Saifetdinova, H.A. (2002) Naukovo-praktychni rekomendatsii z utrymannia laboratornykh tvaryn, ta roboty z nymy [Scientific and practical recommendations for the care of laboratory animals and work with them]. Kyiv: Avitsena [in Ukrainian].

11. Avdieiev, O.V. (2011) Sposib modeliuvannia parodontyta [Modeling method of periodontitis]. Patent $U A$, no. 57189 [in Ukrainian].

12. Avdieiev, O.V. (2011) Sposib modeliuvannia parodontyta [Modeling method of periodontitis]. Patent $U A$, no. 66298 [in Ukrainian]. 
13. Mysula, N.I. (2015). Sposib modeliuvannia zapalnykh protsesiv slyzovoi obolonky porozhnyny rota [Method of simulation of inflammation of the oral mucosa]. Patent UA, no. 98021 [in Ukrainian].

14. Reznikov O.H. (2003) Zahalni etychni pryntsypy eksperymentiv na tvarynakh. Pershyi natsionalnyi konhres z bioetyky [General ethical principles of experiments on animals. First national congress on bioethics]. Endokrynolohiia - Endocrinology, 1 (8). 142-145 [in Ukrainian].

15. Romanenko, E.G. (2013) Strukturnye izmeneniya v slizistykh obolochkakh verkhnikh otdelov pishche- varitelnogo trakta pri eksperimentalnom gastroduodenite [Structural changes in the mucous membranes of the upper digestive tract in experimental gastroduodenitis]. Morfolohiia - Morphology, 7 (1), 73-77. Rretrieved from: http://www.morphology.dp.ua/ [in Ukrainian].

16. Trukhan, L.lu., Tarasova, L.V., \& Trukhan, D.I. (2012). Izmenenie so storony organov i tkanei polosti rta pri bolezniakh organov pishchevareniya [The change from the organs and tissues of the oral cavity in diseases of the digestive system]. Klinicheskaia praktika. Dental Tribune Russian Edition - Clinical Practice. Dental Tribune Russian Edition, 2, 10 [in Russian].

\section{МОРФОМЕТРИЧЕСКАЯ ХАРАКТЕРИСТИКА СЛИЗИСТОЙ ОБОЛОЧКИ ПОЛОСТИ РТА И ИЗМЕНЕНИЯ ПОКАЗАТЕЛЕЙ ГУМОРАЛЬНОГО ИММУНИТЕТА ПРИ ВОЗДЕЙСТВИИ РАЗЛИЧНЫХ ТИПОВ ВОСПАЛИТЕЛЬНОЙ РЕАКЦИИ В УСЛОВИЯХ ЭКСПЕРИМЕНТАЛЬНОГО ГАСТРОДУОДЕНИТА}

\section{Резюме}

Вступление. Слизистая оболочка полости рта является чувствительным индикатором оценки патологических процессов желудочно-кишечного тракта, что обусловлено отличием ее от других слизистых оболочек по морфологическим признакам. При заболевании органов пищеварения, в зависимости от глубины поражения того или иного органа, развиваются морфологические изменения слизистой оболочки всех отделов полости рта и изменения иммунологических показателей в крови животных.

Цель работы - изучить и оценить изменения морфометрических параметров слизистой оболочки полости рта щечной области и изменения показателей гуморального иммунитета при воздействии различных типов воспалительной реакции в условиях экспериментального гастродуоденита.

Методы исследования. Эксперимент выполнено на 84 крысах-самцах массой 180-200 г. У всех животных в течение 7 дней моделировали острый гастродуоденит. Гипоергический тип воспалительной реакции моделировали путем внутримышечного введения алкилирующего цитостатика циклофросфрана, гиперергический - пирогенала. Нормоергический тип развивался у крыс с экспериментальным гастродуоденитом без дополнительного введения каких-либо веществ. Анатомическое препарирование щечной области рта и морфометрические измерения осуществляли по методике Г. Г. Автандилова. Измеряли толщину слизистой оболочки, эпителиального слоя, собственной пластинки, базальной мембраны, удельный вес поврежденных эпителиоцитов остеоподобного слоя, относительный объем капилляров. В сыворотке крови животных определяли уровни $\lg A, M, G$.

Результаты и обсуждение. На основе полученных морфометрических данных изучены и установлены изменения слизистой оболочки полости рта. Причиной уменьшения толщины слизистой оболочки щеки было значительное истончение эпителиального слоя. В то же время другие структурные компоненты слизистой оболочки полости рта щечной области, а именно базальная мембрана и собственная пластинка, наоборот, утолщались. Максимально выраженные дистрофрические изменения эпителия слизистой оболочки щеки при микроскопии были обнаружены у животных с гиперергическим типом воспалительной реакции. Удельный вес поврежденных эпителиоцитов на 10-й день исследования по показателям был увеличен относительно контроля в перечисленных группах. У крыс с гипер-, нормо- и гипоергическим типами воспалительной реакции морфометрические изменения щечной области согласовывались с иммунологическими показателями. Уровни $\lg$ A, M, G были выше относительно контроля во всех исследуемых группах животных.

Выводы. Изменения морфометрических данных сопровождались уменьшением толщины слизистой оболочки и эпителиального слоя, увеличением толщины собственной пластинки, базальной мембраны, удельного веса поврежденных эпителиоцитов остеоподобного слоя и относительного объема капилляров в течение 10 суток эксперимента независимо от типа воспалительной реакции, изменения гуморального иммунитета - возрастанием уровней $\lg$ A, M, G относительно контроля в течение 10 суток. Наиболее значительные изменения были обнаружены у животных с гиперергическим типом воспали- 
тельной реакции, наименьшие - с гипоергическим, у крыс с нормоергическим типом изменения занимали промежуточное место.

КЛЮЧОВЫЕ СЛОВА: морфометрия; слизистая оболочка полости рта; гастродуоденит; гипоергический тип воспалительной реакции; нормоергический тип воспалительной реакции; гиперергический тип воспалительной реакции; иммуноглобулины классов А, M, G.

\section{MORPHOMETRIC CHARACTERISTIC OF THE MUCOUS MEMBRANE OF THE ORAL CAVITY AND CHANGE OF HUMORAL IMMUNITY UNDER THE INFLUENCE OF VARIOUS TYPES OF INFLAMMATORY REACTION IN CONDITIONS OF EXPERIMENTAL GASTRODUODENITIS}

Introduction. Mucous membrane of the oral cavity is a sensitive indicator of evaluation of pathological processes of gastrointestinal tract, due to its morphological features difference compared with other mucous membranes. At digestive system diseases, depending on the lesion level of one organ or another, morphological changes of mucous membrane of all oral cavity parts take place and changes in immunological parameters of animal blood.

The aim of the study - to examine and evaluate changes of morphometric parameters of the mucous membrane of the oral cavity of the buccal area and changes of humoral immunity under the influence of various types of inflammatory reaction at experimental gastroduodenitis.

Materials and Methods. The experimental study was carried out on 42 male rats with weight 180-200 g. For all animals they modeled acute gastroduodenitis during 7 days. Hypoergic type of inflammatory reaction was modeled with intramuscular injection of alkylating cytostatic cyclophosphamide. Hyperergic type was modeled with intramuscular injection of pyrogenal on physiological solution. Normoergic type developed in the animals with experimental gastroduodenitis without additional injection of any substances. Anatomic preparation of the oral cavity buccal area and morphometric measurements were made, using the methodology of H. H. Avtandilov. We measured mucous membrane thickness, epithelial layer, lamina propria, basal membrane, specific gravity of damaged epitheliocytes of osteoid layer, relative volume of capillaries. The level of the concentration of $\lg A, M, G$ in serum was determined.

Results and Discussion. According to the results of the experimental study we found changes in the oral mucosa. The cause of buccal mucous membrane thinning was significant thinning of the epithelial layer. At the same time other structural components of mucous membrane of the buccal area of the oral cavity, namely basement membrane and lamina propria, were thickened on the contrary. The most evident dystrophic changes of the epithelium of buccal mucous membrane at microscopy were revealed in the animals with hyperergic type of inflammatory reaction. Specific part of damaged epitheliocytes, on the 10 day of the study on indicators was increased relatively to control in these listed groups. In rats with hyperergic, normoergic, hypoergic TIR and morphometric changes in buccal areas consistent with immunological parameters. The levels of $\lg A, M, G$ were higher relative to controls in all investigated groups of animals.

Conclusions. Changes of morphometric data were accompanied with thickness decrease of mucous membrane and epithelial layer, increase of thickness of the lamina propria, basement membrane, specific part of damaged epitheliocytes of osteoid layer and capillaries relative volume during 10 days of the experiment regardless of the inflammatory reaction type. Changes in humoral immunity accompanied by rising levels of Ig classes $A, M$ and $G$ relative control within 10 days. The most significant changes were found in animals with hyperergic type of inflammatory reaction, the least - with hypoergic type of inflammatory reaction in animals normoergic type of inflammatory reaction of change took an intermediate position.

KEY WORDS: morphometry; oral cavity; gastroduodenitis; hypoergic type of inflammatory reaction; normoergic type of inflammatory reaction; hyperergic type of inflammatory reaction; immunoglobulins of classes A, M, G.

Адреса для листування: В. І. Бондарчук, Тернопільський державний медичний університет імені І. Я. Горбачевського, м. Волі, 1, Тернопіль, 46001, Україна, e-mail: valentuna 89@ukr.net. 